\title{
Tablet kunyah ekstrak etanol herba pegagan (Centella asiatica (L.), Urban) menurunkan kadar kreatinin tikus putih jantan (Rattus norvegicus L.) galur wistar yang diberi diet lemak tinggi
}

\author{
Akrom $^{1,2}$, Nur Prasetyawan ${ }^{1}$ \\ ${ }^{1 .}$ Fakultas Farmasi Universitas Ahmad Dahlan \\ 2. Pusat Informasi dan Kajian Obat Universitas Ahmad Dahlan \\ Jl. Prof. Dr. Soepomo, S.H., Janturan, Yogyakarta
}

Submitted: 10-09-2016

Reviewed: 02-11-2016

Accepted: 03-11-2016

\begin{abstract}
ABSTRAK
Telah dikembangkan sediaan tablet kunyah ekstrak etanol herba pegagan (TKEEHP) dan telah dilakukan pengujian untuk mengetahui pengaruh pemberian TKEEHP terhadap fungsi ginjal pada tikus yang diberi diet tinggi lemak. Herba pegagan merupakan salah satu tanaman obat yang diduga bersifat nefroprotektor. Tujuan penelitian ini untuk mengkaji pengaruh pemberian TKEEHP terhadap perubahan kadar kreatinin dan ureum serum tikus putih jantan galur Wistar yang telah diberi diet lemak tinggi. Penelitian eksperimental ini dilakukan pada 21 ekor tikus putih galur Wistar berumur 2-3 bulan (berat badan 150-200 gram). Tikus dibagi dalam 7 kelompok masing-masing 3 ekor/kelompok. Kelompok I sebagai kelompok normal, hewan uji mendapatkan makan dan minum standar. Kelompok II, III, IV, V, VI, dan VII hewan uji diberi diet lemak tinggi selama 5 minggu. Pada minggu ke-5 dan ke-6 kelompok III (kontrol positif) diberi Simvastatin ${ }^{\circledR}$, kelompok IV (kontrol media tablet kunyah) diberi tablet plasebo, kelompok V, VI dan VII masing-masing diberi 100, 200 dan $300 \mathrm{mg} / \mathrm{KgBB}$ TKEEHP. Pada akhir minggu ke-6 semua tikus diambil darahnya melalui sinus orbitalis lalu dilakukan uji kadar kreatinin dan ureum serum. Data hasil pemeriksaan kadar kreatinin dan serum kemudian dianalisis dengan uji beda rata-rata antar kelompok (anova) dan LSD dengan tingkat kepercayaaan 95\%. Hasil penelitian menunjukkan tablet kunyah ekstrak etanol herba pegagan (Centella asiatica (L.) Urban) dapat menurunkan kadar kreatinin pada tikus putih jantan galur Wistar yang diberi diet lemak tinggi, tetapi tidak mempengaruhi kadar ureum. Pemberian tablet ekstrak etanol herba pegagan dosis 100, 200, dan 300 $\mathrm{mg} / \mathrm{KgBB}$ berpotensi menurunkan kadar kreatinin dan penurunan kadar kreatinin serum tertinggi pada dosis $300 \mathrm{mg} / \mathrm{KgBB}$.
\end{abstract}

Kata kunci: Tablet kunyah ekstrak etanol herba pegagan (TKEEHP), diet lemak tinggi, kreatinin dan ureum serum

\section{ABSTRACT}

A chewable tablet dosage ethanol extract of herb gotu kola (TKEEHP) has developed. Research to determine the impact of TKEEHP on kidney function has been conducted. Gotu kola herb is one of the medicinal plants that allegedly serves as antioxidative nefroprotektor. The purpose of this study is to assess the effect of TKEEHP on the changes in serum levels of creatinine and urea of male Wistar rats that had been given a high-fat diet. The experimental research was conducted on 21 Wistar rats aged 2-3 months (150-200 g body weight). Rats were divided into seven groups. Group I (normal) was given normal diet. Group II, III, IV, V, VI, and VII were given a high fat diet for 5 weeks. In the week 5 and 6 group III (positive control) was given Simvastatin ${ }^{\circledR}$, group IV was given placebo tablets, and the group V, VI and VII were given 100, 200 and $300 \mathrm{mg} / \mathrm{KgBW}$ TKEEHP, respectively. At the end of week 6 rats have blood drawn through orbital sinus and then tested serum levels of creatinine and urea.

Penulis korespondesi:

Akrom

Fakultas Farmasi UAD

Jl. Prof. Dr. H Soepomo, S.H., Yogyakarta.

Email: akrom@pharm.uad.ac.id 
Data examination of urea and creatinine serum levels were analyzed with ANOVA) and LSD with confience interval of 95\%. The results showed TKEEHP reduce the levels of creatinine in male Wistar rats given a high fat diet, but did not affect serum urea levels. TKEEHP with the dose of $100 \mathrm{mg} /$ $\mathrm{KgBW}, 200 \mathrm{mg} / \mathrm{KgBW}$, and $300 \mathrm{mg} / \mathrm{KgBW}$ show potency to lower creatinine levels and decrease serum creatinine levels at the highest dose of $300 \mathrm{mg} / \mathrm{KgBW}$.

Keywords: Chewable tablet ethanol extract of herb gotu kola (TKEEHP), high fat diet, antioxidants nefroprotektor, serum creatinine and urea

\section{PENDAHULUAN}

Penyakit ginjal kronik merupakan salah satu masalah kesehatan masyarakat di Indonesia (Prodjosujadi, 2006). Insidensi dan prevalensi penyakit ginjal kronik mengalami peningkatan baik di negara maju maupun negara berkembang seiring dengan peningkatan dislipidemia, obesitas dan diabetes melitus (Hwang et al., 2010). Disamping hipertensi dan diabetes melitus, hiperlipidemia adalah salah satu faktor risiko kejadian penyakit ginjal kronik. Hasil penelitian epidemiologi di negara-negara maju menunjukkan adanya hubungan antara hiperlipidemia dengan percepatan kejadian penyakit ginjal kronik (Levey et al.,2007; Vela et al., 2014). Defisiensi heme oksigenase-2 telah dibuktikan berhubungan dengan kejadian stress oksidatif dan kerusakan ginjal yang diperantarai diabetes melitus (Goodman et al., 2006; Newman dan Price, 1999).

Stress oksidatif, inflamasi dan glomerulosklerosis merupakan rangkaian mekanisme kerusakan ginjal pada kondisi hiperlipidemia (Keane, 1994; Scheuer et al., 2000). Telah dibuktikan bahwa interaksi sel mesangial dengan lipid pada perlemakan ginjal memacu proses glomerulosklerosis dan iskemia ginjal yang berujung pada kerusakan ginjal (Fuiano et al., 1995; Keane, 1994; Trevisan et al., 2006). Perlemakan di ginjal ditandai dengan meningkatnya kadar kreatinin dan ureum serum. Adanya peningkatan kadar kreatinin dan ureum serum dalam darah merupakan tanda-tanda umum dari kerusakan ginjal (Nasution et al., 2001; Trevisan et al., 2006).

Flavonoid pada penelitian sebelumnya telah terbukti memberikan perlindungan terhadap terjadinya perlemakan ginjal pada tikus yang diberi diet lemak tinggi (Francesco et al., 2005). Pegagan (Centella asiatica (L.) Urban) merupakan salah satu tanaman yang banyak mengandung flavonoid (Lasmadiwati et al., 2004). Berdasarkan hal-hal tersebut di atas maka penelitian ini dilakukan untuk menguji pengaruh pemberian TKEEHP terhadap perubahan kadar kreatinin dan ureum serum tikus putih jantan (Rattus norvegicus L.) galur Wistar yang telah diberi diet lemak tinggi. Berdasarkan latar belakang tsb maka tujuan penelitian ini adalah untuk melihat pengaruh pemberian TKEEHP terhadap perubahan kadar kreatinin dan ureum serum tikus putih jantan (Rattus norvegicus L.) galur Wistar yang telah diberi diet lemak tinggi.

\section{METODE PENELITIAN}

Alat dan bahan

Peralatan yang digunakan dalam penelitian ini adalah : mikrohematokrit, eppendorf, mikropipet, timbangan hewan, lemari es, sentrifuge, tabung-tabung sentrifuge mikro, alat-alat gelas, spektrofotometer, alat suntik, dan pipa kapiler. Bahan yang digunakan dalam penelitian ini adalah : TKEEHP yang sudah disiapkan sebelumnya oleh tim peneliti bagian teknologi; tablet Simvastatin $10 \mathrm{mg}$ yang diperoleh dari Apotek UAD Yogyakarta, minyak babi dengan pemberian peroral yang dicampur dengan pakan PKN.124/BR2/VIII/2004 (1:9), Urease, TRIS pH 7,8, 2-Oksoglutarat, NADH, GLDH, $\mathrm{NaOH}$ dan Asam Pikrat.

Hewan uji yang digunakan dalam percobaan ini adalah tikus putih jantan (Rattus norvegicus L.) galur Wistar dengan umur 2-3 bulan dengan berat badan awal 150-200 gram yang diperoleh dari Laboratorium Penelitian dan Pengujian Terpadu Universitas Gadjah Mada unit IV (LPPT UGM unit IV), Yogyakarta.

\section{Prosedur Penelitian \\ Penetapan dosis TKEEHP dan simvastatin}

Berdasarkan hasil penelitian yang dilakukan oleh Gnanapragasam et al., (2004), dosis ekstrak etanol herba pegagan (Centella asiatica (L.) Urban) yang berfungsi untuk mengurangi indikasi terjadinya 
Infark Miokard adalah $200 \mathrm{mg} / \mathrm{Kg}$ BB tikus Wistar. Dosis tersebut kemudian ditetapkan variasi kadar dosis tabet kunyah, untuk mendapatkan dosis optimum dalam penelitian ini, yaitu $100 \mathrm{mg} / \mathrm{Kg} \mathrm{BB}, 200$ $\mathrm{mg} / \mathrm{Kg} \mathrm{BB}$, dan $300 \mathrm{mg} / \mathrm{Kg}$ BB tikus, yang dikonversikan menjadi 20,40 dan $60 \mathrm{mg} / 200 \mathrm{~g}$ BB tikus.

\section{Pembuatan Diet Lemak Tinggi}

Diet berdasarkan penelitian yang dilakukan oleh Nuryanti (2001) makanan untuk meningkatkan kadar lipid darah tikus pembuatannya dilakukan dengan cara pakan tikus standar BR II dicampur minyak babi dengan perbandingan 90:10 sedikit demi sedikit sampai homogen. Pakan ini dibuat setiap hari selama diet lemak tinggi dan perlakuan.

\section{Persiapan Hewan Uji}

Tikus jantan galur Wistar berumur 2-3 bulan dipilih secara acak menjadi 7 kelompok masingmasing 3 ekor dan masing-masing tikus dikandangkan sesuai kelompok untuk menghindari kesalahan pemberian perlakuan. Tikus diadaptasikan selama 1 minggu, kemudian diberi perlakuan dengan pemberian diet lemak tinggi pada kelompok II, III, IV, V, VI, dan VII selama 5 minggu. Minggu keempat sampai minggu kelima hewan uji diberi tablet kunyah ekstrak etanol herba pegagan (Centella asiatica (L.) Urban) dengan tetap memberikan pakan diet lemak. Tablet kunyah ekstrak etanol herba pegagan telah disiapkan oleh bagian Teknologi Farmasi Fakultas Farmasi UAD. Pemberian tablet kunyah ekstrak etanol pegagan (Centella asiatica (L.) Urban) dilakukan secara peroral. Hewan uji tikus karena tidak bisa mengunyah tablet seperti yang dilakukan pada manusia maka tablet kunyah ekstrak etanol herba pegagan (Centella asiatica (L.) Urban) dihancurkan terlebih dahulu menjadi beberapa bagian lalu dimasukkan ke dalam mulut tikus untuk langsung masuk ke esofagus. Pemeriksaan kadar kreatinin dan ureum serum dilakukan pada akhir minggu kelima. Pengambilan darah untuk pemeriksaan kadar kreatinin dan ureum serum melalui sinus orbitalis dengan menggunakan mikrohematokrit. Kelompok I sebagai kontrol pakan dengan tidak diberi tablet kunyah ekstrak etanol herba pegagan (diberi akuades), kelompok II sebagai kontrol negatif diberi pakan diet lemak, kelompok III sebagai kontrol positif (diet lemak + simvastatin), kelompok IV sebagai kontrol media (diet lemak + tablet plasebo), kelompok V diberi diet lemak dan tablet kunyah ekstrak etanol herba pegagan (Centella asiatica (L.) Urban) dengan kadar $100 \mathrm{mg} / \mathrm{Kg} \mathrm{BB}$, kelompok VI diberi diet lemak dan tablet kunyah ekstrak etanol herba pegagan (Centella asiatica (L.) Urban) dengan kadar $200 \mathrm{mg} / \mathrm{Kg} \mathrm{BB}$, dan kelompok VII diberi diet lemak dan tablet kunyah ekstrak etanol herba pegagan (Centella asiatica (L.) Urban) dengan kadar $300 \mathrm{mg} / \mathrm{Kg}$ BB pada masing - masing tikus.

\section{Mengukur kadar kreatinin dan ureum serum.}

Pengujian kadar kreatinin dan ureum serum dilakukan di LPPT unit 1 Universitas Gadjah Mada. Dalam pemeriksaan kadar kreatinin dan ureum serum spesimen yang digunakan adalah serum tikus.

\section{Penyiapan Serum}

Tikus putih jantan galur Wistar diambil darahnya melalui sinus orbitalis sebanyak $\pm 1,5 \mathrm{ml}$. Darah ditampung ke dalam Eppendorf, didiamkan selama 15 menit, kemudian dipusingkan dengan kecepatan $4000 \mathrm{rpm}$ selama 10 menit dan diambil supernatannya (serum).

\section{Pemeriksaan ureum dan kreatinin}

Pada analisis fotometri ureum tikus putih jantan galur Wistar yang diberi diet lemak tinggi dilakukan sebagaimana formulasi dari Newman dan Price (1999). Pembuatan monoreagen dilakukan dengan cara mencampur empat bagian R1 dengan satu bagian R2.Tahap selanjutnya bahan dicampur. Kemudian dibaca perubahan absorbansinya dengan spektrofotometer pada panjang gelombang $340 \mathrm{~nm}$ dengan operating time setelah 1 menit selama 2 menit.

\section{Perhitungan Kreatinin dan Ureum}

Hasil pembacaan absorbansi dihitung dengan cara sebagai berikut:

$\Delta$ A sampel $\mathrm{x}$ konsentrasi standar $=(\mathrm{mg} / \mathrm{dI})$

$\Delta \mathrm{A}$ standar

Keterangan:

$\Delta \mathrm{A}$ sampel : perubahan absorbansi sampel

$\Delta \mathrm{A}$ standar : perubahan absorbansi standar 
Konsentrasi standar kreatinin : $2 \mathrm{mg} / \mathrm{dI}$

Konsentrasi standar ureum : $50 \mathrm{mg} / \mathrm{dI}$

\section{Analisis Data}

Data kadar kreatinin dan ureum serum yang didapat kemudian di olah dengan software statistic SPSS 16. Data yang telah didapat di uji normalitas dengan Kolmogorov-Smirnov dan homogenitas dengan uji Levene terlebih dahulu untuk menentukan data termasuk data yang parametrik atau non parametrik. Berdasarkan hasil uji normalitas dan homogenitas diketahui bahwa data kadar ureum dan kreatinin adalah parametrik. Dilakukan uji beda rata-rata kadar ureum dan kreatinin antar semua kelompok dengan anova dengan taraf kepercayaan $95 \%$ bila signifikansi yang dihasilkan $<0,05$ dapat disimpulkan ada perbedaan rata-rata dari masing-masing kelompok perlakuan. Setelah diketahui ada perbedaan pada masing-masing perlakuan analisis dilanjutkan untuk mengetahui ada perbedaan signifikan atau tidak antar kelompok perlakuan dengan uji LSD.

\section{HASIL DAN PEMBAHASAN}

Aktifitas antioksidan dari kandungan TKEEHP diharapkan dapat menghambat kerusakan ginjal akibat radikal reaktif yang dihasilkan dari proses lipolisis akibat kelebihan lemak tubuh. Hasil pengamatan kadar kreatinin dan ureum disajikan pada Tabel I

Tabel I. Kadar ureum dan kreatinin tikus SD diet lemak tinggi dengan diberikan tablet kunyah ekstrak etanol herba pegagan (TKEEHP)

\begin{tabular}{lcc}
\hline \multicolumn{1}{c}{ Kelompok } & Kadar kreatinin (mg/dl) & Kadar ureum (mg/dl) \\
\hline I.Normal & $0,37 \pm 0,058$ & $33,60 \pm 3,69$ \\
II.Kontrol negativ (diet tinggi lemak) & $0,53 \pm 0,058^{*}$ & $29,27 \pm 2,49$ \\
III.Kontrol positif (simvastatin) & $0,27 \pm 0,12^{*}$ & $25,07 \pm 4,55^{*}$ \\
IV.Placebo & $0,43 \pm 0,058^{*}$ & $107,80 \pm 24,12^{* a b c}$ \\
V.TKEEHP100 & $0,40 \pm 0,10^{* a b c}$ & $53,10 \pm 12,36^{* a b c}$ \\
VI.TKEEHP200 & $0,38 \pm 0,06^{\mathrm{abc}}$ & $67,87 \pm 13,48^{* \mathrm{abc}}$ \\
VII.TKEEHP300 & $0,37 \pm 0,045^{\mathrm{abc}}$ & $42,60 \pm 14,06^{* \mathrm{abc}}$ \\
\hline
\end{tabular}

\begin{tabular}{ll}
\hline Keterangan: & : mendapatkan makan minum stand \\
normal & : diet tinggi lemak \\
kontrol negatif & : diet lemak tinggi+simvastatin \\
kontrol positif & : diet lemak tinggi+plasebo \\
plasebo & : diet lemak tinggi+tablet kunyah \\
TKEEHP100 & : diet lemak tinggi + tablet kunyah \\
TKEEHP200 & : diet lemak tinggi+tablet kunyah \\
TKEEHP300 & *=berbeda bermakna dengan kelompok normal \\
a=berbeda bermakna dengan kelompok kontrol negativ \\
b=berbeda bermakna dengan kelompok kontrol positif \\
c=berbeda bermakna dengan kelompok plasebo
\end{tabular}

Hasil penelitian menunjukkan bahwa diet lemak tinggi memberikan efek perubahan kadar kreatinin pada hewan uji. Kadar kreatinin kelompok kontrol negatif, yang mendapatkan diet lemak tinggi, memiliki kadar kreatinin lebih tinggi dari kelompok normal $(0,53 \pm 0,058$ v.s. $0,37 \pm 0,058 ; p<0,05)$. Pemberian TKEEHP berpengaruh terhadap kadar kreatinin hewan uji. Kadar kreatinin pada kelompok kontrol negatif $(0,53 \pm 0,058)$ lebih tinggi jika dibandingkan dengan kadar kreatinin kelompok TKEEHP, kelompok kontrol positif memiliki kadar kreatinin terendah $(0,27 \pm 0,12)$ dan bermakna secara statistik. Kadar kreatinin kelompok TKEEHP dosis $100 \mathrm{mg} / \mathrm{KgBB}$ adalah $0,40 \pm 0,10 \mathrm{mg} / \mathrm{dI}, 0,38 \pm 0,06$ pada

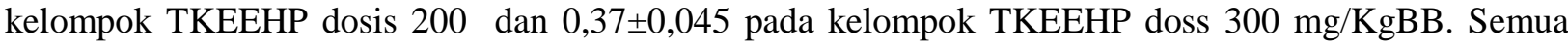
kelompok TKEEHP memiliki kadar kreatinin lebih rendah dari kelompok kontrol negatif $(\mathrm{p}<0,05)$. Namun kemampuan TKEEHP dalam menurunkan kadar kreatinin akibat diet lemak tinggi tidak sekuat simvastatin. Kelompok simvastatin memiliki kadar kreatinin paling rendah $(0,27 \pm 0,12 \mathrm{mg} / \mathrm{dI})$ diantara kelompok hewan uji.

Dari hasil penelitian diketahui bahwa diet lemak tinggi tidak terbukti mempengaruhi kadar ureum darah. Rata-rata kadar ureum kelompok diet lemak tinggi (kontrol negatif) dan rata-rata kadar ureum 
kelompok normal tidak berbeda secara statistik $(\mathrm{p}>0,05)$. Kelompok plasebo memiliki rata-rata kadar ureum paling tinggi dan berbeda bermakna dengan kelompok normal dan kontrol negatif. Kelompok TKEEHP memiliki rata-rata kadar ureum lebih rendah dari kelompok plasebo, namun lebih tinggi dari rata-rata kadar ureum kelompok normal $(\mathrm{p}<0,05)$.

Salah satu fungsi ginjal adalah melakukan filtrasi terhadap berbagai substansi toksik dalam tubuh, antara lain kreatinin dan ureum serum (Trevisan et al., 2011). Berdasarkan hasil pemeriksaan kadar kreatinin pada tikus yang mendapat pemberian TKEEHP dosis 100 , 200, dan 300mg/KgBB mempunyai kadar kreatinin serum yang lebih rendah dari pada kadar kreatinin serum pada kontol negatif (diberi lemak tinggi) dan perubahan tersebut memberikan perbedaan yang signifikan $(\mathrm{p}<0,05)$. Hasil penelitian ini menunjukkan bahwa TKEEHP dosis 100, 200 dan $300 \mathrm{mg} / \mathrm{kgBB}$ memiliki efek nefroprotektor pada tikus yang diinduksi dengan diet lemak tinggi. Mekanisme nefroprotektor TKEEHP diduga melalui peningkatan aktifitas sekresi kreatinin sehingga kadar kreatinin kelompok TKEEHP lebih rendah dari kelompok kontrol negatif. Rata-rata kadar kreatinin kelompok TKEEHP tidak berbeda dengan rata-rata kadar TKEEHP kelompok kontrol positif $(p>0,05)$. Hasil penelitian ini menunjukkan bahwa kemampuan TKEEPH sebagai penurun kadar kreatinin sama dengan simvastatin. Efektivitas simvastatin dalam menghambat kejadian gagal ginjal pada kondisi hiperlipidemia telah dibuktikan. Simvastatin dapat menurunkan kadar kreatinin dan ureum serum serta mengurangi tingkat keparahan gagal ginjal kronik melalui mekanisme antioksidan dan antiinflamasi (Jandeleit-Dhm et al., 1999; Mehra, 2011). Kadar kreatinin dan ureum serum yang normal sesuai dengan teori adalah $0,48 \mathrm{mg} / \mathrm{dl}$ untuk kreatinin dan 41,56 $\mathrm{mg} / \mathrm{dl}$ untuk ureum (Brito et al., 2005). Telah dibuktikan adanya hubungan antara hiperlipidemia dengan gangguan fungsi ginjal. Ketiadaan bilirubin turunan heme oksigenase dan karbon monoksida menyebabkan menurunnya superoksida dan berakibat pada peningkatan kadar kreatinin plasma serta kerusakan mikrovaskuler maupun tubular ginjal. Heme oksigenase berperan sebagai regulator dalam ekspresi sitokrom P450 renal dan sintesis asam 20-hidroxycosatetraenoic yaitu asam yang mengatur fungsi renal dan respon vaskuler (Goodman et al., 2006). Diet tinggi lemak dapat meningkatkan kadar kolesterol darah (Scheuer et al., 2000). Menurut Nuryanti (2001) induksi lemak babi yang dicampur dengan pakan standard (10:90) selama 3 minggu dapat menaikkan kadar kolesterol darah tikus. Hasil ini diperkuat oleh adanya laporan penelitian yang dilakukan Nastiti et al., (2008) bahwa pemberian pakan dengan komposisi tersebut dapat meningkatkan kadar LDL dalam darah dan menunjukkan perbedaan yang signifikan dengan kelompok normal.

Telah diketahui bahwa herba pegagan kaya dengan kandungan flavonoid dan triterpenoid (Hasyim et al., 2011). Telah dibuktikan juga bahwa ekstrak pegagan efektif menurunkan kholesterol total maupun trigliserid pada hewan uji hiperlipidemia (Zhao et al., 2014). Penurunan kadar kreatinin yang terjadi pada kelompok yang diberi TKEEPH kemungkinan merupakan aktivitas antioksidatif senyawa triterpenoid atau flavonoid yang terkandung di dalam pegagan tersebut (Hasyim et al., 2011; Hussin et al., 2008). Menurut Hasyim et al., (2011) flavonoid merupakan antioksidan yang efektif dalam sistem oksidasi kimia yang mampu mencari dan mengambil berbagai radikal bebas seperti peroksil, alkil peroksil, superoksida, hidroksil, nitrit oksida dan peroksinitrit dalam lingkungan organik. Flavonoid juga dapat menghambat agregasi trombosit dan mempunyai efek vasodilatasi. Vasodilatasi akan meningkatkan laju filtrasi glomerulus sehingga kadar kreatinin serum akan menurun. Asiatikosida telah dibuktikan berhubungan dengan reaksi inflamasi melalui reseptor TGF-b1 (Lee et al., 2006).

Pada hasil pengukuran kadar ureum, untuk tikus yang diberi diet lemak tinggi (kontrol negatif) tidak memperlihatkan peningkatan kadar ureum yang signifikan bila dibandingkan dengan tikus normal. Berarti pada penelitian ini pemberian diet lemak tinggi tidak memberikan pengaruh terhadap perubahan kadar ureum pada tikus. Kadar ureum serum yang tidak menunjukkan perbedaan yang signifikan pada semua kelompok dapat juga dikarenakan pada data kadar ureum serum memiliki variasi biologis yang besar, hal ini dikarenakan perlakuan tikus pada masing-masing kelompok perlakuan tidak menggunakan kandang tikus secara individual sehingga masing-masing tikus pada suatu kelompok mungkin mendapat jumlah diet lemak tinggi yang tidak seragam. Variasi biologis yang besar mungkin juga dikarenakan daya tahan stres pada setiap tikus berbeda-beda. Dari hasil ini didapat bahwa penetapan kreatinin darah untuk mengevaluasi fungsi ginjal dianggap lebih spesifik dari penetapan ureum. Produksi kreatinin berhubungan dengan massa otot, aktivitas otot dan masukan kreatin yang banyak berasal dari daging. Kreatinin plasma merupakan indeks laju filtrasi glomerulus (LFG) yang lebih cermat dari BUN, karena kecepatan produksinya dan terutama merupakan fungsi massa otot yang perubahan (Trevisan et al., 2006). 


\section{KESIMPULAN}

Tablet kunyah ekstrak etanol herba pegagan (Centella asiatica (L.) Urban) dapat menurunkan kadar kreatinin serum pada tikus putih jantan galur Wistar yang diberi diet lemak tinggi. tetapi tidak mempengaruhi kadar ureum serum pada tikus putih jantan galur Wistar yang diberi diet lemak tinggi.

\section{UCAPAN TERIMAKASIH}

Penulis menyampaikan terima kasih yang sebesar-besarnya kepada Dirjen Dikti Depdiknas yang telah memberikan dana untuk pelaksanaan penelitian.

\section{DAFTAR PUSTAKA}

Brito, M. V. H., Moreira, R. de Jesus, Tavares, M. L. C., Carballo, M. C. S., Carneiro, T. X., Santos dos santos, A de Assis. 2005, Copaiba oil effect on urea anf creatinine serum levels in rats submitted to kidney isvhemia and reperfusion syndrome. Acta Cirurgica. 20 (3):243-246.

Francesco, P., Duarte, J., Jimenez, R., Buelga, C.,Osuna, A., 2008, Antihypertensive effects of the flavonoid quercetin, Institute of Pharmacology, Spanyol.

Fuiano, G., Esposito, C., Sepe, V., Colucci, G., Bovino, M., M., Rosa., Balleta, M., Bellinghieri, G., Conte, G., Cianciaruso.1995, Effects hypercholesterolemia on hemodynamics kidney, Faculty of Nephrology, Itali.

Goodman, Alvin, I., Praveen, N Chander, Rita Rezzani, Michael L Schwatzman, Raymond F Regan, Luigi Rodella, Saade Turkseven, Elias A Lianos, Phyllis A Dennery. 2006, Heme oxygenase-2 deficiency contributes to diabetes-mediated increase in superoxide anion and renal dysfunction. Journal of The American Society of Nephrology.17: 1073-1081.

Hashim, P., Sidek, H., Helan, M.H.M., Sabery, A.,Palanisamy, U.D., Ilham, M., 2011, Triterpene composition and bioactivities of Centella asiatica, Molecules 2011, 16, 1310-1322.

Hussin, A., Hamid, A., Mohamad, S., Saari, N., Bakar, F., Dek, S.P., 2008, Modulation of Lipid Metabolism by Centella Asiatica in Oxidative Stress Rats, Faculty of Food Science and Biotechnology, Univ. Putra Malaysia, Malaysia.

Hwang, S-J., Tsai, J.C., Chen, H., 2010, Epidemiology, Impact and preventive care of chronic kidney disease in Taiwann, Nephrology 15, 3-9.

Jandeleit-dahm, K., Cao, Z., Cox, A.J., Kelly, D.J., Gilbert, R.E., Cooper, M.E., 1999, Role of hyperlipidemia in progressive renal disease:Focus on diabetic nephropathy, Kidney International, 56(71)31-36.

Keane, I.F., 1994, Lipids and the kidney, Kidney International, 46:910 — 920.

Lasmadiwati, E., Herminati, M.M., Indriani, Y.H., 2004, Pegagan, Penebar Swadaya, Jakarta.

Lee, J., Jung, E, Kim, Y., Park J, Park J, Hong S, Kim J, Hyun C, Kim YS, Park D, 2006. Asiaticoside induces human collagen i synthesis through tgfbeta receptor kinase (Tbetari Kinase)-independent smad signaling, Mol Cell Biochem. ;294(1-2):55-63.

Levey, A.S., Atkins, R., Coresh, J., Cohen, E.P., Collins, A.J., Eckardt, K-U., Nahas, M.E., Jaber8, B.L., 2007, chronic kidney disease as a global public health problem: approaches and initiatives - a position statement from kidney disease improving global outcomes, Kidney International advance online publication.

Mehra, S., \& Desa, T., 2011, Statins in chronic kidney disease- are statins really renoprotective, $J$ Nephrol Therapeutic 1:103.

Nastiti, K., Agustin, D. T., Ekawati, K. M., Wahyu, A. P., Widyatno, H., 2008, Tablet kunyah ekstrak etanol herba pegagan (Centella asiatica (L.) Urban) sebagai pencegah jantung koroner, Laporan Penelitian, Fakultas Farmasi Universitas Ahmad Dahlan, Yogyakarta.

Nasution, M.Y. \& Prodjosudjadi, W., 2001, Pemeriksaan penunjang pada penyakit ginjal, ilmu penyakit dalam, Jilid II. Ed: Suyono, Slamet H, Waspadji, Sarwono dkk, Balai Penerbit FKUI,Gaya Baru, Hal: 301-303.

Newman, D.J., \& Price, C.P., 1999, Renal function and nitrogen metabolites. Texbook of Clinical Chemistry edisi 3.Philadelpia: WB Saunders Company, Hal: 366-374.

Nuryanti, S., 2001, Pengaruh pemberian ekstrak etanol daun seledri (Apium graveolens L) terhadap penurunan kadar kolesterol total serum darah tikus putih jantan galur Wistar yang diberi diet lemak tinggi. Skripsi, Fakultas Farmasi, Universitas Ahmad Dahlan. Yogyakarta. Hal: 68-69. 
Prodjosudjadi, W., 2006, Incidence, Prevalence, Treatment and cost of end-stage renal disease in Indonesia, Ethnicity dan Disease, 16.

Scheuer, H., Gwinner, W., Hohbach, J., Grone, E.F., Brandes, R.P., Malle, E., Olbright, C.J., Walli, A.K., Josef, H.J.,2000,Oxidant stress in hyperlipide-induced renal demage,.University of Munich, Jerman.

Trevisan,T., Dodesini, A.R., Lepore, G. 2006, Lipids and Renal Disease, J Am Soc Nephrol 17: S145S147.

Vela, X.F., Henríquez, D.O., Zelaya, S.M., Granados, D.V., Hernández, M.X., Orantes, C.M., 2014,Chronic kidney disease and associated risk factors in two salvadoran farming communities, 2012, MEDICC Review, 16 (2).

Zhao, Y., Shu, P., Zhang, Y., Lin, L., Zhou, H., Xu, Z., Suo, D., Xie, A., Jin, X., 2014, Effect of Centella asiatica on oxidative stress and lipid metabolism in hyperlipidemic animal models, Hindawi Publishing Corporation Oxidative Medicine and Cellular Longevity, 2014. 
